\title{
STRATEGIES OF FAMILIES IN THE CARE OF CHILDREN WITH CHRONIC DISEASES
}

\author{
Marli dos Santos Salvador ${ }^{1}$ Giovana Calcagno Gomes², Pâmela Kath de Oliveira³, Vera Lúcia de Oliveira \\ Gomes $^{4}$, Josefine Busanello ${ }^{5}$, Daiani Modernel Xavier ${ }^{6}$
}

\footnotetext{
${ }^{1}$ Master's Student, Pós-Graduação em Enfermagem, Escola de Enfermagem (EEnf), Universidade Federal do Rio Grande (FURG). Rio Grande, Rio Grande do Sul, Brazil. E-mail: marli-salvador@hotmail.com

2 Ph.D. in Nursing. Faculty at EEnf/FURG. Rio Grande, Rio Grande do Sul, Brazil. E-mail: giovanacalcagno@furg.br

${ }^{3}$ Master's student, Programa de Pós-Graduação em Enfermagem at EEnf/FURG. Rio Grande, Rio Grande do Sul. Brazil. E-mail: pamelakathpko@yahoo.com.br

${ }_{4}^{4}$ Ph.D. in Nursing. Faculty at EEnf/FURG. Rio Grande, Rio Grande do Sul. Brazil. E-mail: vlogomes@terra.com.br

${ }^{5}$ Ph.D. in Nursing. Graduação em Enfermagem at Universidade Federal do Pampa. Uruguaiana, Rio Grande do Sul, Brazil. E-mail: josefinebusanello@unipampa.edu.br

${ }^{6}$ Ph.D. Student, Programa de Pós-Graduação em Enfermagem at EEnf/FURG. Grantee CAPES. Rio Grande, Rio Grande do Sul. Brazil. E-mail: daiamoder@ibest.com.br
}

\begin{abstract}
A descriptive and exploratory research was carried out using a qualitative approach, in a Pediatric Unit of a university hospital in the south of Brazil, during the first and second halves of 2013. The study involved 15 participating families. Data were collected by means of interviews subjected to thematic analysis. It was identified as strategies: balance work, study and care, share tasks throughout the day, adapt the physical area of the house, engage the child in their own care, seek resources in the network of social support and faith, seek assistance in another city; and engage in physical activity to reduce stress. It was concluded that it is necessary that the nurses participate of the family support network, as a support source for the strengthening of the family to the care, acquiring skills and expertise to a positive coping of the child's chronic disease.
\end{abstract}

DESCRIPTORS: Nursing. Child. Chronic Disease. Family. Nursing care.

\section{ESTRATÉGIAS DE FAMÍLIAS NO CUIDADO A CRIANÇAS PORTADORAS DE DOENÇAS CRÔNICAS}

RESUMO: Objetivou-se conhecer as estratégias de famílias no cuidado a crianças portadoras de doenças crônicas. Realizou-se uma pesquisa descritiva e exploratória, com abordagem qualitativa, em uma Unidade de Pediatria de um hospital universitário do Sul do país, no primeiro e segundo semestres de 2013. Participaram 15 familiares. Os dados foram coletados por entrevistas submetidas à análise temática. Como estratégias foram identificadas: conciliar trabalho, estudo e cuidados; dividir as tarefas ao longo do dia; adaptar a área física da casa; envolver a criança no seu próprio cuidado; buscar recursos na rede de apoio social e na fé; procurar assistência em outra cidade; e realizar atividade física para fortalecer-se e reduzir o estresse. Concluiu-se como necessário que o enfermeiro torne-se parte da rede de apoio da família, sendo fonte de suporte para que a mesma consiga fortalecer-se para o cuidar, adquirindo habilidades e competências para o enfrentamento positivo da doença crônica da criança.

DESCRITORES: Enfermagem. Criança. Doença crônica. Família. Cuidados de enfermagem.

\section{ESTRATEGIAS DE LAS FAMILIAS EN EL CUIDADO DE NIÑOS CON ENFERMEDADES CRÓNICAS}

RESUMEN: Este estudio tuvo como objetivo conocer las estrategias de cuidado de niños con enfermedades crónicas, realizadas por las familias. Se realizó un estudio cualitativo descriptivo, exploratorio en una unidad pediátrica de un hospital universitario en el sur del Brasil, en 2013. Participaron 15 familiares. Los datos fueron recolectados a través de entrevistas y sometidos a análisis temático. Fueran identificadas las siguientes categorías: conciliar trabajo, estudio y asistencia; dividir las tareas a lo largo del día, adaptar el espacio físico de la casa, incluir a los niños en su propio cuidado, buscar recursos en la red de apoyo social y la fe, buscar ayuda en otra ciudad y realizar actividad física para reducir el estrés. Se concluyó que las enfermeras deben de formar parte de la red de apoyo a la familia, para que la misma pueda fortalecerse para el enfrentamiento positivo de la enfermedad crónica del niño.

DESCRIPTORES: Enfermería. Niño. Enfermedad crónica. Familia. Cuidados de enfermería. 


\section{INTRODUCTION}

The profile of hospitalized Brazilian children is in the process of change, with increased number of children with chronic diseases in recent decades and reduction in the prevalence of acute diseases. This phenomenon is observed worldwide. ${ }^{1}$ Chronic disease is that which affects the functions of the individual in his/her daily activities for more than three months/year, because hospitalization for a month or a year requires the use of special equipment of adjusting, which can undermine the family, temporary or eventually, definitively. ${ }^{2}$

In Brazil, the incidence of chronic diseases among children aged from zero to 14 years is $9.3 \%$. Pollution, fast-food consumption and inadequate diets contributed to the development of asthma, rhinitis, obesity and diabetes in children. Asthma is the most common chronic disease in childhood, affecting more than $10 \%$ of Brazilian children and from $1 \%$ to $2 \%$ of low-age children in Brazil have food allergy. The understanding of the Primary Immunodeficiencies (PIDs) is increasing and, in Brazil, there are about 160,000 carriers of different types of PIDs; from $6 \%$ to $8 \%$ of the population experiences some kind of autoimmune disease and type 1 diabetes mellitus is particularly significant. Moreover, from $5 \%$ to $10 \%$ of all diabetic patients in Brazil are children or adolescents. ${ }^{3}$

Chronic illness in childhood undermines children and their family. Generally, the family does not expect the diagnosis of the child is a long or incurable disease. The feelings of the parents may be intense as result of cultural issues of protection of children and affective bonds formed from gestation. The coping with the diagnosis can cause physical and psychological strain, especially for the caregiver. The relatives of these children become people with special needs, since they need guidance on how to deal with the problem, regarding the reorganization of family structure and strategies of coping with the disease and its sequelae. ${ }^{4}$

Children with chronic diseases require frequent hospitalizations and special care. This can cause pain and direct material costs to their families, contributing to the increase of poverty. ${ }^{5}$ Family is the main base of support, and is considered the first social unit where the individual is part and the first institution that contributes to the development and socialization of individuals. ${ }^{6}$

When someone falls ill, it is necessary that one of the family members assumes the care. This is a dynamic process, which is in constant construction, deconstruction and reconstruction, making it remarkable, especially when the carrier of chronic disease is a child. This care requires from the family a reorganization of roles given the child's needs, causing a significant impact on the dynamics and lives of people living with a child with chronic illness. ${ }^{7}$

At the time that the child's caregiver (family, close people or institutions hosting these children) is informed about the condition of chronic disease, this person starts to experience a period of conflict. This faces changes and new requirements in his/ her daily routine. Often, it is necessary to implement difficult adjustments into everyday life that will interfere at various levels: financial, occupational, and personal and in the relationships, both within the family and outside of it. Furthermore, in the face of chronic disease, it is common the incidence of moments of exacerbation or recurrence of symptoms in the child, which undermine the entire family dynamics, since, during the manifestation of the disease, the family can go into crisis and fall apart. ${ }^{8}$

In many families, the mother is the primary caregiver of the child because, in some cases, the father is not able to deal with the material and emotional overload that the child with chronic disease requires, mainly the emotional overload. This highlights, in part, the wide presence of mothers as family caregivers of children during their hospitalization and outpatient appointments. ${ }^{8}$

On these occasions, special assistance must be offered. The social support network that the family has to provide childcare should be taken into account. ${ }^{9}$ This network comprises a group of people with whom the individual has bonds. Among these are the relatives, neighborhood, work colleagues and the circle of friends. ${ }^{10}$ The family also needs emotional support to feel capable and motivated to continue caring for the child. This support should be constant and appropriate for each situation experienced, since at each stage of the disease, the family has special needs. Therefore, the support must be individualized and unique, as each individual has its own characteristics and ways of coping. ${ }^{11}$

In some situations, the family caregiver has technical knowledge limitations, given the type of care to be performed, for example, insulin administration, the ostomy bags handling, feeding tubes, condensers and oxygen catheters, vacuum extractors, nebulizers, etc. In such cases, it is necessary to overcome difficult emotional and 
intellectual barriers in order to acquire skills and competencies to care.

In a study on the family care provided to the child at home, it was verified the need for re-adaptation of family daily life due to the need of performing daily technical procedures such as bladder catheterization, administration of continuous use drugs, prevention of skin lesions and orthosis. Moreover, it was investigated the attendance of ongoing consultation of the child to outpatient and rehabilitation services. ${ }^{12}$

Throughout the time the child with chronic illness is growing, gaining weight and height, requiring physical changes in his/her own care at the home environment and new demands on family caregivers. In addition to the emotional commitment that often comes from the difficulties of social life, the caregiver may feel physically limited to care, having his/her health compromised.

This fact is worsened by the absence or deficiency of support network and basic support in the home environment and in the community. Social support has an informational dimension on the resources provided by members of the network, causing the family caregiver of children with chronic disease care in an instrumentalized way. ${ }^{13}$ In addition, government financial aid is also important, because it is additional in the support to the family to meet the demands imposed by the chronic disease of the child. ${ }^{11,14}$

Based on the above, home care for children with chronic disease becomes a challenge to be managed by the family. Consequently, this must organize itself to find out how to handle and face the child's chronic condition.

In this context, the question that guided this study was: what are the strategies employed by the family in the care of children with chronic disease? From this question, it was aimed to know the strategies of families in caring for children with chronic diseases.

\section{METHOD}

This is a descriptive and exploratory study with a qualitative approach, ${ }^{15-16}$ carried out in the Pediatrics Unit of a University Hospital (UH) in the South of Brazil, in the first and second halves of 2013. Participants were 15 family members of children with chronic disease hospitalized in the period of data collection.

The inclusion criteria were: be the main caregiver of children with chronic disease at home and accompany them during their hospitalization and provide them with direct care. Family caregivers who were not accompanying the child in the hospital at the time of data collection or refused to participate in the study were excluded. The participants signed the Free and Informed Consent Form.

Data collection was carried out through interviews with each participant, which were operationalized by means of a script with questions about family care for children with chronic disease and their experiences with this care. The interviews were performed in the infirmary where the child was hospitalized, recorded and posteriorly transcribed. Data were analyzed using thematic analysis and optimized from pre-analysis, from which the speeches grouping and preparation of reporting units were performed; exploitation of the material in which the data were encoded and organized into categories, and processing and interpretation of the results achieved, from which the most significant statements were selected to illustrate the analysis, and the search for other authors in the literature to support analysis was performed. ${ }^{15}$

The ethical principles of research involving human were respected, according to Resolution $466 / 12 .{ }^{17}$ The research project was submitted to the Research Ethics Committee of the Health Area (CEPAS/FURG) and obtained a favorable opinion under the number 106/2013. The speeches of the participants were identified by the letter F followed by the interview number, in order to ensure their confidentiality and anonymity.

\section{RESULTS}

Next, the characterization of the families of the study will be presented and the categories generated from the thematic analysis of the data, i.e. Conciliating study, work and care; Adapting the physical area and keeping the house clean; Engaging the child with chronic disease in his/ her own care; Seeking funds in the network of social support; Practicing physical activity as a way to strengthen and reduce stress; and Searching through the use faith, the ability to cope with the chronic disease.

\section{Characterization of families participating in the study}

Study participants were 15 families of children with chronic diseases. The main caregiver of every child is the mother, representing the families 
of this study. They were aged between 21 and 43 years. Five had incomplete elementary education, three had complete elementary education, six had complete high school education and only one was attending college, however it was a distance-learning mode course. They have been living with the chronic disease of the child from five to 12 years. Eight children have chronic disease from birth.

Five mothers have never had paid work outside the home, four work (two are cleaners, one is a nursing assistant and one is a piece worker at a fish factory), six had to stop working to take care of the child. They live with one to four minimum wages per month. They maintain three to seven people with this income. Regarding the contribution to the family income, in six families, the father was the only provider; in five families, in addition to the father's salary, they received benefit of continuing provision; and in two families, both the father and the mother contributed to the income; one family had the benefit of continuing provision as the only income; and one family had only the mother as provider. These caregivers receive help from their partners (five) and from the grandparents of children (three) to care for the child. The others take care of the child alone.

The children were aged between 5 and 12 years (to be completed) and presented as chronic disease the encephalopathy (five children), pulmonary stenosis, asthma (three kids), osteogenesis imperfecta, hyperactivity, bladder reflux for bad urethral formation, increase in cervical lymph nodes for more than one year, short bowel syndrome, post-resection of the intestine of $90 \%$, blindness and ileostomy for seven years. The children in the study had several hospitalizations over time, and of these, four attended the Association of Parents and Friends of Exceptional (APAE), three were attending pre-school, three were attending the fourth grade of elementary school and two were attending the fifth grade of elementary school. The others remained at home. They had special needs, since 13 used daily medication and eight used other types of care technologies such as nasal catheters, peripherally inserted venous catheters, colostomy bags, wheelchairs, nebulizers, walkers, pump spray, gastrostomy tube, among others.

\section{Conciliating work, study and care}

The family was reorganized in order to support the main caregiver for childcare. Some caregivers try to conciliate work, study and care and, to this end, they seek to work close to the residence and organize their work activities so that it does not match their spouse's work shifts.

The strategy I have found to conciliate the care to my daughter and work was getting a job close to home. Thus, I can go home to take a look and find out how she is (F3).

For one family, it was observed that both the father and the mother are organized in order to follow the child full time in the classroom. They believe that this is the only way she can keep up with the data content and handle her physical dependence.

I try to combine work and care for my son because he is dependent: he uses a wheelchair. My husband and I organized our work activities so that always one of us stay in the classroom with him daily. Thus, we believe that he might keep up with the other classmates in learning. The school does not have a tutor only for him. The college I'm attending is a distance learning mode, which enables me to stay with him and study (F8).

It was also found that the brothers take turns in caring for children with chronic diseases studying in opposite shifts so that their mother can work.

My other older daughters study in reverse shifts. Then one is taking care of her in the morning, and the other one in the afternoon. The ease I have is that I can count on my daughters; otherwise, I would not be able to work and financially support the home (F3).

In order to organize themselves to care, the family performs the division of the activities during the 24 hours of the day. They try to optimize their time in providing direct care to the child and home activities enabling a pleasant and healthy environment for the child.

I try to divide my time during the day. I give the medication in the morning and do the housework. In the afternoon, I go to physiotherapy with him. Currently, I'm going two days a week. When we are at home, he has fun watching TV. Then, I do other household tasks (F1).

\section{Adapting the physical area and keeping the house clean}

Another strategy used by the family to care for the child is to adapt the physical area of the house and keep it clean in order to provide safety, comfort and quality of life for the child.

The strategy I have found to keep her asthma attacks has been changing things inside, I removed the curtains and carpets, changed the floor because it was wet and installed wooden floor (F7). 
If we leave in the morning, in the afternoon I cleaned the house. I keep everything clean so he has no breathing problems. I spend the day with a cleaning cloth in my hand to prevent dust (F1).

It is not something that you cannot take care of. I keep my house clean, dust free, no curtains or carpets and I clean the furniture and the floor with a damp cloth every day (F6).

\section{Engaging children with chronic diseases in their own care}

Among the strategies used by caregivers, the child is involved in his/her own care. They teach the child to take care of him/herself, with their collaboration, especially at times when the caregiver is not with them. They mentioned that is better to take care of an obedient child, which cooperate and protect themselves from temperature changes.

The convenience to take care of him is that he is obedient and cooperative. I made sure to teach him to take care of himself early. He protects himself from exposure to the cold. I avoid uncovering his chest when there are temperature changes (F9).

There's no other way. I know that he is little and full of problems, but his case is serious. He has to know how to take care of himself. To care for the PICC catheter not to contaminate and undergo special diets. I have taught him everything. He has to get involved in care. Thus, he can become more committed. His life depends on it (F11).

\section{Seeking funds in the social support network}

They perform care in order to avoid the complications of the disease. They take care of the child's food, medicate them as prescription and take them to be assisted in the hospital when they realize this need.

The strategies I use range from taking care of his feeding, I got him not to get wet, not to catch cold. His diet is special. The Department of Health purchases it of a company. The process to achieve it was difficult, but now it is all right (F11).

I do everything I have to do. When fever starts, I go to the doctor. The measures I adopt are: give medication and seek health services. But, I get nervous, panicky until I bring her to the hospital (F10).

I got a single bed for him at the hospital. Then he can rest calmly. I also organized the remedies in a closet, all separate, avoiding losing, or the other kids that are small catching and taking. I get advice from professionals in the health care unit and I always get home visits (F4).

Some families leave their city in search of better conditions and seek assistance in major specialized care centers.

I moved to Porto Alegre. There he has a better assistance and a team of several professionals. All qualified, with various specialties here I had no access (F12).

We had to move to Brasilia. There he has several professional and fully equipped hospital. My husband managed his work relocation (F13).

\section{Practicing physical activity as a way to strengthen and reduce stress}

One of the caregivers attempts to fill her time with physical activity while her child is at APAE. This activity gives her pleasure, but also strengthens her muscles that are widely used for the care provided. In addition, to perform a physical activity aids in reducing stress.

There in the APAE he is treated as an equal. I practice physical exercises while he is in the APAE. I go to the gym every day while he's busy. While he's in therapy I try to reconcile his time with mine. I do medically indicated because my spine is damaged because of the effort I make to him. Thus, I need to strengthen the muscles. But, it is also a way to relieve stress (F2).

\section{Searching through the use faith to face the chronic diseases}

There are moments in the life of the caregiver he/ she believes that there is no solution. He search on faith in God the hope to protect his/her child. They mentioned that faith gives them hope that strengthens to continue taking care of the children with chronic disease and not despair.

There is not much to do. A doctor tells you something and another one says another: that your child will not survive and has little time to live, but there he is with nine years of age. So I just pray and leave in God's hands. If not for the faith, I would have lost hope and given myself and maybe he would not be here with me? (F8).

Soon after his birth, I had depression. I had no courage to do any thing. I was always out of home; I did not want to go home without my son. When he entered the ICU, only I asked God to look after him. I held much in God. Thus, I knew it was the faith in God that gave me the strength to face all (F9). 


\section{DISCUSSION}

The care of children with chronic disease is complex, requiring the family to implement strategies for its coping. A study that aimed to understand the experience of mothers in the care of children with chronic disease revealed that the role of protection that parents have with their children is something intrinsic of relationships. In this sense, the primary caregiver is faced with the challenge of harmonizing the maternal functions to professional. Childcare becomes priority over work. ${ }^{18}$

Caring for a child with chronic diseases can generate accumulation of demands on the family, requiring a redefinition of roles so there is no burden on the primary caregiver. Generally, the first support comes from relatives. The families reorganize themselves in order to be able to help. This support consists in subsidizing the family caregiver in all his/her needs, so that he/she can devote himself/herself to the care of children, making him/her more confident and secure. ${ }^{13}$

Considering that the treatment of the chronic disease of the child requires periodic hospitalizations and continuous monitoring, its coping requires from the family more than time availability, it requires dedication, reorientation of finance, tasks and commitment to the reorganization of family daily lives. This shows that the family caregiver needs to create a new organization to take care. $^{19}$

A study involving children with chronic disease suggests that beyond the care provided directly to the child, in many cases, there is a need to adapt the physical space of the house aiming to make it more secure and facilitating care. In this study, among these adaptations, it was mentioned removing carpets, curtains, plants, pets, intensifying domestic hygiene as the most recommended measure for crisis prevention and ensuring safety and comfort. ${ }^{20}$

Another care strategy used by the family is the inclusion of children with chronic disease in their own care. The knowledge that children with chronic diseases have about their infirmity and self-care requirements related to them, can give them basis for the continuation of adequate therapy and prevention of recurrence of the disease. ${ }^{21}$ When individuals with chronic diseases assume an active role in their health-disease process, they contribute to the reduction of recurrent hospitalizations and suffering resulting from it.
Consequently, they can get better a quality of life and a better adaptation to the disease. ${ }^{22}$

The child's health recovery desire is manifested also by seeking support in the spiritual dimension according to the experience of the family. To have faith and believe in God is essential to gain strength for the hard living with the disease and face the reality. ${ }^{23-24}$ During the child's disease, the hope in his/her recovery appears as a mainstay that keeps the family and strengthens it emotionally. Faith in God represents another powerful source of support, regardless of religion. ${ }^{13}$

Faced with the installation of a chronic disease in children, the family uses several strategies, which includes the care centered in preserving the health of the child and the search for health professionals and better-equipped hospitals. In recent years, it has been considered the importance of a network of social support to the family in the face of its everyday demands.

The social support network is composed of people who have social bonds with each other. Social support has the informative dimension of the resources provided, generating physical, emotional and beneficial behaviors. Social support involves exchanging relationships, providing accessibility and reliability, as well as emotional, inclusive, material and cognitive resources, etc., causing the individual to abstract a bit from the focus of his/her problem. ${ }^{13}$

The care for the child can involve changes from municipality or state. This fact showed that access to health services could be a complicating element, causing a lot of inconvenience for families, since many of them are forced to move from a city within the state to some reference center established in the capital for treatment of a certain disease, often traveling long distances in inadequate transportations.

Participants reported the frustration of not having specialized health institutions to treat their children in their hometowns. ${ }^{25}$ Caring for the needs of children with chronic disease becomes part of daily family life, occupying the living of the family, which feels responsible for maintaining the quality of life of the child. ${ }^{26}$

In a research that addresses the factors influencing the quality of life of caregivers of children with chronic disease, participants reported having physical pain during the course of childcare. In this study, it was evident that, in some cases, the pain prevents family members to perform their daily activities, since the caregivers of children with 
special needs have lower physical performance, decreased vitality, stress and little time for practice of physical activities. ${ }^{18}$

Thus, it was noticed that family caregivers need to allocate time to take care of themselves in order to devote themselves in the best way to care for the child. ${ }^{27}$ Given the above, it is essential that the caregiver creates strategies that enables the practice of some physical activity. The challenge for caregivers is to balance the care demands of chronic condition of their child and their quality of life.

Nursing care can be focused on reducing the impact of care demands of children to their caregivers and better family functioning, improving the lives of both the child and his/her relatives. ${ }^{28}$ These should be the central focus for which health professionals provide help, developing strategies for emotional support, strengthening and information. ${ }^{23}$

\section{CONCLUSIONS}

The study aimed to know the strategies of families in caring for children with chronic diseases. The data show that the diagnosis of chronic disease in childhood causes intense reaction in the family who needs to find coping strategies in its everyday family life, having to reorganize itself in order to care for the child.

As strategies of family for caring of children with chronic diseases, it was identified: conciliate work, study and care, divide the tasks throughout the day, adapt the physical area of the house, engage the child in his/her own care, seek resources in the social support network and faith; seek assistance in another city and practice physical activity to be strengthened and reduce stress.

It is assumed that, usually, when the family members living for a while with the disease seek the professionals, they already have knowledge that enables them to take part in care decisions. Therefore, rather than participate, it is important to establish a partnership with family, creating opportunities to listen and support aiming a shared construction of childcare.

To know the family strategies in the care of children with chronic diseases is fundamental to subsidize nursing practice for these families and their children. The nurse can provide information and assistance in the instrumentalization of the family to exercise its role as the child's caregiver, making it an effective source of support. The family care for children with chronic disease is com- plex, requiring dedication and support. It is a singular care established and provided in accordance with the child's daily needs. The home represents a privileged place for family care, deserving a different attention from health professionals.

Thus, the nursing performance should also be focused on family so that it acquires balance and quality of life, even in the context of chronic disease. Accordingly, it becomes part of the social support network of the family; however, working together at home can be a reliable source of support, so that family can be strengthened to care, acquiring skills and competences needed for a positive coping of chronic disease of the child and autonomy for thinking and acting.

It is necessary to enable the family to prevent disease sequelae by planning specific care actions. To perform objective evaluations, both for the child and the family dynamics, become effective sources of support and care to them. Therefore, it is necessary to distinguish their needs, identify their individual and collective demands, using information and communication as therapeutic tools available to take care, favoring the reduction of their difficulties to face the process of chronic disease in child.

New studies on the strategies used by family caregivers of children with chronic diseases to take care at home and on how nurses may mediate this care, should be performed in order to enable the provision of an effective, humanized and quality care, both for the child with chronic disease as for the family caregivers.

\section{REFERENCES}

1. Costa MTF, Gomes MA, Pinto M. Dependência crônica de ventilação pulmonar mecânica na assistência pediátrica: um debate necessário para o SUS. Ciênc Saúde Coletiva. 2011; 16(10):4147-59.

2. Torpy JM, Campbell A, Glass R. Chronic diseases of children. JAMA. 2010; 303(7):682.

3. Marchioro AB, Martins MR. Diabetes mellitus tipo 1 em crianças e adolescentes: implicações para a família. UNINGÁ Review. 2010; 4(5):80-7.

4. Gondim KM, Pinheiro PNC, Carvalho ZMF. Participação das mães no tratamento dos filhos com paralisia cerebral. Rev Rene. 2009; 10(4):136-44.

5. Malta DC, Silva JR JB. O Plano de Ações Estratégicas para o enfrentamento das doenças crônicas não transmissíveis no Brasil e a definição das metas globais para o enfrentamento dessas doenças até 2025: uma revisão. Epidemiol Serv Saúde. 2013; 22(1):151-64. 
6. Araújo I, Paul C, Martins M. Cuidar no paradigma da desinstitucionalização. A sustentabilidade do idoso dependente na família. Rev Enf Ref Série. 2010; III(2):45-53.

7. Nóbrega VM, Reichert IPS, Silva K, Coutinho SED, Collet N. Imposições e conflitos no cotidiano das famílias de crianças com doenças crônicas. Esc Anna Nery Rev Enferm. 2012; 16(4):781-8.

8. Martins AJ, Cardoso MHCA, Llerena Junior JC, Moreira MCN. A concepção de família e religiosidade presente nos discursos produzidos por profissionais médicos acerca de crianças com doenças genéticas. Ciênc Saúde Coletiva. 2012; 17(2):545-53.

9. Motta MGC, Issi HB, Ribeiro NRR. Grupos como estratégia de ensino e cuidado de família, criança e adolescente com doença crônica. Cienc Cuid Saude 2009; 8(supl):155-61.

10. Bittencourt ZZLC, Françozo MFC, Monteiro C, Francisco DD. Surdez, redes sociais e proteção social. Ciênc Saúde Coletiva. 2011; 16(Supl. 1):769-76.

11. Araújo YB, Reichert APS, Oliveira BRG, Collet N. Rede e apoio social de famílias de crianças com doença crônica: revisão integrativa. Cienc Cuid Saúde. 2011; 10(4):853-60.

12. Gaiva MAM, Neves AQ, Siqueira FMG. O cuidado da criança com espinha bífida pela família no domicílio. Esc Anna Nery Rev Enferm. 2009; 13(4):717-25.

13. Gomes GC, Pintanel AC, Strasburg AC, Erdmann AL. O apoio social ao familiar cuidador durante a internação hospitalar da criança. Rev Enferm UERJ. 2011; 19(1):64-9.

14. Nóbrega RD, Collet N, Gomes IP, Holanda ER, Araújo YB. Criança em idade escolar hospitalizada: significado da condição crônica. Texto Contexto Enferm. 2010; 19(3):425-33.

15. Minayo MCS. O desafio do conhecimento: pesquisa qualitativa em saúde. São Paulo (SP): HucitecAbrasco; 2010.

16. Triviños ANS. Introdução à pesquisa em ciências sociais: a pesquisa qualitativa em educação. São Paulo (SP): Atlas; 2009.

17. Ministério da Saúde (BR). Conselho Nacional de Saúde. Resolução n. 466, de 12 de dezembro de 2012: dispõe sobre diretrizes e normas regulamentadoras de pesquisa envolvendo seres humanos. Brasília
(DF): MS; 2012.

18. Almeida KM, Fonseca BM, Gomes AA, Oliveira MX. Fatores que influenciam a qualidade de vida de cuidadores de paralisados cerebrais. Fisioter Mov. 2013; 26(2):307-14.

19. Silva MAS, Collet N, Silva Kl, Moura FM. Cotidiano da família no enfrentamento da condição crônica na infância. Acta Paul Enferm. 2010; 23(3):359-65.

20. Medeiros LMC, Vieira RS, Javorski M. Identification of risk for wheezing at home by caregivers. Rev Enferm UFPE [online]. 2011 [acesso 2014 Jan 20]; 5(1). Disponível em: http://www.revista.ufpe.br/ revistaenfermagem/index.php/revista/article/ viewArticle/1359

21. Sousa MLXF, Silva KL, Nóbrega MML, Collet N. Déficits de autocuidado em crianças e adolescentes com doença renal crônica. Texto Contexto Enferm [online]. 2012 [acesso 2014 Jan 21]; 21(1). Disponível em: http://www.scielo.br/pdf/tce/v21n1/ a11v21n1.pdf

22. Novais E, Conceição AP, Domingos J, Duque V. O saber da pessoa com doença crônica no autocuidado. Rev HCPA. 2009; 29(1):36-44.

23. Costa ASM, Britto MCA, Nóbrega SM, Vasconcelos MGL, Lima LS. Vivências de familiares de crianças e adolescentes com fibrose cística. Rev Bras Crescimento Desenvolv Hum. 2010; 20(2):217-27.

24. Lauver LS. The lived experience of foster parents of children with special needs living in rural areas. J Pediatric Nurs. 2010; 25(4):289-98.

25. Pedroso MLR, Motta MGC. Criança e família convivendo com a doença crônica: mesossistema em ligação com a vulnerabilidade programática. Texto Contexto Enferm. [online]. 2013 [acceso 2014 Jan 21]; 22(2):493-9. Disponível em: http:/ / www.scielo.br/ $\mathrm{pdf} / \mathrm{tce} / \mathrm{v} 22 \mathrm{n} 2 / \mathrm{v} 22 \mathrm{n} 2 \mathrm{a} 27 . \mathrm{pdf}$

26. Silveira A, Neves ET. Crianças com necessidades especiais em saúde: cuidado familiar na preservação da vida. Cienc Cuid Saúde. 2012; 11(1):74-08.

27. Leite MF, Gomes IP, Leite MF, Oliveira BRG, Rosin J, Collet N. Condição crônica na infância durante a hospitalização: sofrimento do cuidador familiar. Cienc Cuid Saúde. 2012; 11(1):51-7.

28. Christiam BJ. Research commentary-challenges for parents and families: Demands of caregiving of children with chronic conditions. Pediatr Nurs. 2010; 25(4):299-301. 